\title{
Plot size and number of replications for ryegrass experiments
}

\author{
Marcos Toebe ${ }^{1^{*}(\mathbb{D})}$ Alberto Cargnelutti Filho ${ }^{2} \mathbb{D}$ Juliana Oliveira de Carvalho ${ }^{3}$ (D) \\ Francieli de Lima Tartaglia ${ }^{4}$ Alessandra Ferreira Cortes ${ }^{5}$ (D) Anderson Chuquel Mello S $^{\mathbb{D}}$ \\ Patrícia Jesus de Melo ${ }^{4}$ (i)
}

${ }^{1}$ Departamento de Ciências Agronômicas e Ambientais, Universidade Federal de Santa Maria (UFSM), 98400-000, Frederico Westphalen, RS, Brasil. E-mail: m.toebe@gmail.com. *Corresponding author.

${ }^{2}$ Departamento de Fitotecnia, Universidade Federal de Santa Maria (UFSM), Santa Maria, RS, Brasil.

${ }^{3}$ Programa de Pós-graduação em Biologia Celular e Molecular, Universidade Federal do Rio Grande do Sul (UFRGS), Porto Alegre, RS, Brasil. ${ }^{4}$ Programa de Pós-graduação em Agronomia (UFSM), Santa Maria, RS, Brasil.

${ }^{5}$ Curso de Agronomia, Universidade Federal do Pampa (Unipampa), Itaqui, RS, Brasil.

\begin{abstract}
The objective of this research was to determine the optimal plot size and the number of replications to evaluate the fresh matter of ryegrass sown to haul. Twenty uniformity trials were conducted, each trial with 16 basic experimental units (BEU) of $0.5 \mathrm{~m}^{2}$. At 117,118 and 119 days after sowing, the fresh matter of ryegrass in the BEUs of 5, 10 and 5 uniformity trials, respectively, were determined. The optimal plot size was determined by the maximum curvature method of the variation coefficient model. Next, the replications number was determined in scenarios formed by combinations of $i$ treatments $(i=3,4, \ldots 50)$ and d minimum differences between means of treatments to be detected as significant at 5\% of probability by the Tukey test, expressed in experimental mean percentage (d =10, 11, ... 20\%). The optimal plot size to determine the fresh matter of ryegrass seeded at the haul is $2.19 \mathrm{~m}^{2}$, with a variation coefficient of $9.79 \%$. To identify as significant at $5 \%$ probability, by the Tukey test, differences between treatment means of $20 \%$, are required five, six, seven and eight replications, respectively, in ryegrass experiments with up to 5, 10, 20 and 50 treatments.
\end{abstract}

Key words: Lolium multiflorum L., uniformity trials, experiment planning, maximum curvature method.

Tamanho de parcela e número de repetições para experimentos na cultura do azevém

RESUMO: Os objetivos deste trabalho foram determinar o tamanho ótimo de parcela e o número de repetições para avaliar a massa verde de azevém semeado a lanço. Foram conduzidos 20 ensaios de uniformidade, sendo cada ensaio composto por 16 unidades experimentais básicas (UEB) de 0,5 m². Aos 117, 118 e 119 dias após semeadura foi determinada a massa verde de azevém nas UEB de 5 , 10 e 5 ensaios de uniformidade, respectivamente. Foi determinado o tamanho ótimo de parcela pelo método da curvatura máxima do modelo do coeficiente de variação. A seguir, foi determinado o número de repetições em cenários formados pelas combinações de $i$ tratamentos $(i=3$, 4, ..., 50) e d diferença mínima significativa do teste de Tukey a 5\% de probabilidade, expressa em percentagem da média do experimento (d = $10 \%$, $11 \%$, ..., 20\%). Conclui-se que o tamanho ótimo de parcela para determinar a massa verde de azevém semeado a lanço é de 2,19m², com coeficiente de variação de 9,79\%. Para identificar como significativas a 5\% de probabilidade pelo teste de Tukey, diferenças entre médias de tratamentos de 20\%, o número de repetições necessárias é de cinco, seis, sete e oito repetições, respectivamente, para experimentos com até 5 , 10 , 20 e 50 tratamentos na cultura do azevém.

Palavras-chave: Lolium multiflorum L., ensaios de uniformidade, planejamento experimental, método da curvatura máxima.

\section{INTRODUCTION}

The ryegrass (Lolium multiflorum L.) is the annual winter pasture with the largest cultivated area in the state of Rio Grande do Sul (BISCAÍNO et al., 2018). Ryegrass is an important forage used in dairy production, with ease natural reseeding, disease resistance, high seed production potential and versatility in intercropping (CASSOL et al., 2011). In this sense, dairy cows grazing ryegrass pasture, with a high forage allowance, can eat more than $16.0 \mathrm{~kg}$ dry matter/cow.day and produce more than $20 \mathrm{~kg}$ milk/ day (RIBEIRO FILHO et al., 2009). The ryegrass can also be used in no-till system for crop rotation, ensuring high yields of the successor crop, such as corn (VIZIOLI et al., 2018).
For research on ryegrass to be scientifically valid, it is essential to define the experimental planning. In ryegrass experiments, were used plots from four plants until plots with areas of $108 \mathrm{~m}^{2}$ and three to eight replications (FLORES et al., 2008; CASSOL et al., 2011; AGOSTINETTO et al., 2017; VIZIOLI et al., 2018). However; although, experimental planning has already been carried out for forage crops, such as oat (CARGNELUTTI FILHO et al., 2014; LAVEZO et al., 2017), forage pea (CARGNELUTTI FILHO et al., 2015), millet (BURIN et al., 2016), vetch (CARGNELUTTI FILHO et al., 2017) and rye (CHAVES et al., 2018), no experimental planning studies were reported for ryegrass.

In experimental planning, the optimal plot size can be defined by the maximum curvature 
method of the variation coefficient model proposed by PARANAÍBA et al. (2009). The number of replications can be defined by the iterative process until the convergence, in scenarios formed by combinations of $\mathrm{i}$ treatments and $\mathrm{d}$ minimum differences among means of treatments to be detected as significant by the Tukey test (CARGNELUTTI FILHO et al., 2014, 2015, 2017). Using these methods, was recommended: a plot size of $4.14 \mathrm{~m}^{2}$ and four replications to evaluate the fresh matter of black oats (CARGNELUTTI FILHO et al., 2014); a plot size of $5.03 \mathrm{~m}^{2}$ and four replications to evaluate the fresh matter of forage pea (CARGNELUTTI FILHO et al., 2015); a plot size of $4.97 \mathrm{~m}^{2}$ and five replications to evaluate millet shoot fresh matter (BURIN et al., 2016); a plot size of $1.57 \mathrm{~m}^{2}$ and four replications to evaluate grain yield in four oat cultivars (LAVEZO et al., 2017); a plot size of 4.52 $\mathrm{m}^{2}$ and four replications to evaluate the fresh matter of vetch (CARGNELUTTI FILHO et al., 2017); and, a plot size of $6.08 \mathrm{~m}^{2}$ and seven replications to evaluate grains yield of rye (CHAVES et al., 2018). The objective of this research was to determine the optimal plot size and the number of replications to evaluate the fresh matter of ryegrass sown to haul.

\section{MATERIALS AND METHODS}

Twenty uniformity trials were conducted with ryegrass, BRS Ponteio cultivar, in the experimental area of the Federal University of Pampa, Campus Itaqui, located in the municipality of Itaqui, Rio Grande do Sul State, Brazil, in geographic coordinates latitude $29^{\circ} 09^{\prime} 25^{\prime \prime} \mathrm{S}$, longitude $56^{\circ} 33^{\prime}$ 16 " $\mathrm{W}$ and altitude of $74 \mathrm{~m}$. According to Köppen climate classification, the climate of the region is Cfa, subtropical humid without dry season defined (WREGE et al., 2012) and the soil is classified as "Haplic Plinthosol" (SANTOS et al., 2013).

The ryegrass seeds were sown to haul on June 9, 2015, in an area of $720 \mathrm{~m}^{2}$, with $25 \mathrm{~kg}$ of seeds per hectare. Fertilization was carried out according to the crop recommendation (CQFS, 2004). The cultural practices were performed evenly, as recommended for the uniformity trials (STORCK et al., 2016). Then, in the experiment central area were delimited 20 uniformity trials, each one of size $8 \mathrm{~m}^{2}(4 \mathrm{~m} \times$ $2 \mathrm{~m}$ ), was divided into 16 basic experimental units (BEU) of $0.5 \mathrm{~m}^{2}(1.0 \mathrm{~m} \times 0.5 \mathrm{~m})$, forming a matrix with four rows and four columns. In five trials, at 117 days after sowing (DAS), in ten trials at 118 DAS and in five trials at 119 DAS, in each BEU, the plants were cut near the soil surface and the fresh matter weight determined in grams per $0.5 \mathrm{~m}$.
For each uniformity trial, the following statistics were determined based on the fresh matter weight: first-order spatial autocorrelation coefficient $(\rho)$, variance $\left(\mathrm{s}^{2}\right)$, mean $(\mathrm{m}, \mathrm{g})$, variation coefficient of the trial $\left(\mathrm{CV}_{\text {trial }}, \%\right)$, optimal plot size (Xo, in BEU and $\mathrm{m}^{2}$ ) and the variation coefficient in the optimal plot size $\left(\mathrm{CV}_{\mathrm{Xo}}, \%\right)$. The estimate of $\rho$ was obtained in the direction of the rows, according to the equation described by PARANAÍBA et al. (2009).

Based on the maximum curvature method of the variation coefficient model, proposed by PARANAÍBA et al. (2009), the optimal plot size $\mathrm{Xo}=\left(10 \sqrt[3]{2\left(1-\rho^{2}\right) \mathrm{s}^{2} \mathrm{~m}}\right) / \mathrm{m}$ and the variation coefficient in the optimal plot size $\mathrm{CV}_{\mathrm{Xo}}=\left(\sqrt{\left(1-\rho^{2}\right) \mathrm{s}^{2} / \mathrm{m}^{2}}\right) / \sqrt{\mathrm{Xo}} \times 100$ were determined. The means comparisons of the statistics $\rho, \mathrm{s}^{2}, \mathrm{~m}, \mathrm{CV}, \mathrm{Xo}$, and $\mathrm{CV}_{\mathrm{Xo}}$ were performed at $5 \%$ probability as follows: the three evaluation periods were compared by the Tukey test via bootstrap with 10,000 resampling's, preceded by the variance analysis (a factor, that is, evaluation time with three levels) via bootstrap with 10,000 resampling's. In these variance analyses, the trials were considered replications (independent samples). The variance analysis and the Tukey test via bootstrap were performed in the SISVAR application. These statistical procedures are adequate to circumvent possible impacts of failure to meet the errors normality assumptions and the residual variances homogeneity (FERREIRA, 2014).

For the replications number calculation, it was started from the least significant difference (d) of the Tukey test, expressed in percentage of the experiment general mean, estimated by the equation, $d=\left(q_{\alpha(i ; \text { DFE })} \sqrt{M S E / r}\right) / m \times 100$ where $q_{\alpha(i ; D F E)}$ is the critical value of the Tukey test at level $\alpha$ of error probability ( $\alpha=0.05$, in this study), $i$ is the number of treatments, DFE is the number of freedom degrees of the error, i.e., [i(r-1)] for the completely randomized design and [(i-1) (r-1)] for the randomized block design, MSE is the error mean square, $r$ is the replicates number and $\mathrm{m}$ is the experiment mean. Thus, replacing the expression of the experimental variation coefficient $(\mathrm{CV}=\sqrt{\mathrm{MSE}} / \mathrm{m} \times 100)$, in percentage, in the expression for the calculation of $\mathrm{d}$ and isolating $\mathrm{r}$, we have $\mathrm{r}=\left(\mathrm{q}_{\alpha(\mathrm{i} ; \mathrm{DFE})} \mathrm{CV} / \mathrm{d}\right)^{2}$. In the study, the $\mathrm{CV}$ is expressed as a percentage and corresponds to the $\mathrm{CV}_{\mathrm{Xo}}$, since this is the $\mathrm{CV}$ expected for the experiment with the optimal plot size (Xo) determined.

From the mean of $\mathrm{CV}_{\mathrm{Xo}}$, between the evaluation times, the number of replications (r), by the iterative process until convergence, was determined for experiments in completely randomized design 
and randomized block design, in scenarios formed by combinations of $i$ treatments $(i=3,4, \ldots 50)$ and $d$ minimum differences among treatments means to be detected as significant at $5 \%$ probability by the Tukey test, expressed as a percentage of the experiment mean $(\mathrm{d}=$ $10 \%, 11 \%, \ldots 20 \%$ ). Statistical analyses were performed with the aid of the Microsoft Office Excel ${ }^{\circledR}$ application and the software SISVAR (FERREIRA, 2014)

\section{RESULTS AND DISCUSSION}

There were no differences between the three evaluation times for estimates of the first-order spatial autocorrelation coefficient $(\rho)$, variance $\left(\mathrm{s}^{2}\right)$, mean $(\mathrm{m})$, variation coefficient of the trial $\left(\mathrm{CV}_{\text {trial }}\right)$, optimal plot size (Xo) and the variation coefficient in the optimal plot size $\left(\mathrm{CV}_{\mathrm{Xo}}\right)$ of the fresh matter weight for ryegrass seeded on the haul (Table 1). This is expected given the proximity between the evaluation dates. Thus, the mean values of the statistics were used based on the 20 uniformity trials.

The fresh matter weight of ryegrass ranged between 1166 and $1705 \mathrm{~g}$ per BEU of $0.5 \mathrm{~m}^{2}$, with an overall mean of $1397 \mathrm{~g}$ per BEU or $27940 \mathrm{~kg}$ ha $^{-1}$ (Table 1). The overall mean of the first-order spatial autocorrelation coefficient was close to zero,

Table 1 - First-order spatial autocorrelation coefficient $(\rho)$, variance $\left(\mathrm{s}^{2}\right)$, mean $(\mathrm{m})$, variation coefficient of the trial (CV), optimal plot size (Xo, in BEU of $0.5 \mathrm{~m}^{2}$ and in $\mathrm{m}^{2}$ ) and the variation coefficient in the optimal plot size $\left(\mathrm{CV}_{\mathrm{Xo}_{0}}\right)$ for the fresh matter of ryegrass (Lolium multiflorum L.) - BRS Ponteio cultivar seeded to haul - evaluated in uniformity trials at 117, 118 and 119 days after sowing.

\begin{tabular}{|c|c|c|c|c|c|c|c|c|}
\hline Days after sowing & Trial $^{(1)}$ & $\rho$ & $s^{2}$ & $\mathrm{~m}(\mathrm{~g})$ & $\mathrm{CV}(\%)$ & Xo (BEU) & Xo $\left(\mathrm{m}^{2}\right)$ & $\mathrm{CV}_{\mathrm{Xo}}(\%)$ \\
\hline 117 & 1 & 0.45 & 67932 & 1705 & 15.29 & 3.34 & 1.67 & 7.47 \\
\hline 117 & 2 & 0.34 & 88096 & 1227 & 24.19 & 4.70 & 2.35 & 10.51 \\
\hline 117 & 3 & -0.08 & 58922 & 1249 & 19.43 & 4.22 & 2.11 & 9.43 \\
\hline 117 & 4 & 0.08 & 58266 & 1268 & 19.04 & 4.16 & 2.08 & 9.30 \\
\hline 117 & 5 & 0.24 & 158711 & 1268 & 31.42 & 5.71 & 2.85 & 12.76 \\
\hline Mean & & $0.21 \mathrm{a}^{(2)}$ & $86385 a$ & $1343 a$ & $21.87 \mathrm{a}$ & $4.42 \mathrm{a}$ & $2.21 \mathrm{a}$ & $9.89 a$ \\
\hline 118 & 1 & 0.02 & 96375 & 1559 & 19.91 & 4.29 & 2.15 & 9.60 \\
\hline 118 & 2 & 0.29 & 90709 & 1556 & 19.36 & 4.09 & 2.05 & 9.15 \\
\hline 118 & 3 & -0.14 & 71316 & 1346 & 19.84 & 4.26 & 2.13 & 9.52 \\
\hline 118 & 4 & -0.28 & 61475 & 1397 & 17.74 & 3.87 & 1.94 & 8.66 \\
\hline 118 & 5 & -0.16 & 140335 & 1449 & 25.85 & 5.07 & 2.53 & 11.33 \\
\hline 118 & 6 & -0.38 & 154096 & 1551 & 25.30 & 4.78 & 2.39 & 10.69 \\
\hline 118 & 7 & 0.27 & 88064 & 1497 & 19.82 & 4.18 & 2.09 & 9.34 \\
\hline 118 & 8 & -0.34 & 57289 & 1424 & 16.81 & 3.68 & 1.84 & 8.23 \\
\hline 118 & 9 & -0.10 & 124103 & 1447 & 24.35 & 4.90 & 2.45 & 10.95 \\
\hline 118 & 10 & 0.25 & 112832 & 1441 & 23.31 & 4.67 & 2.33 & 10.43 \\
\hline Mean & & $-0.06 a$ & $99659 a$ & $1467 \mathrm{a}$ & $21.23 \mathrm{a}$ & $4.38 \mathrm{a}$ & $2.19 \mathrm{a}$ & $9.79 a$ \\
\hline 119 & 1 & 0.18 & 84062 & 1482 & 19.57 & 4.20 & 2.10 & 9.39 \\
\hline 119 & 2 & 0.19 & 100572 & 1261 & 25.15 & 4.96 & 2.48 & 11.09 \\
\hline 119 & 3 & 0.18 & 31959 & 1406 & 12.71 & 3.15 & 1.58 & 7.05 \\
\hline 119 & 4 & 0.17 & 57754 & 1244 & 19.32 & 4.17 & 2.08 & 9.32 \\
\hline 119 & 5 & 0.32 & 104872 & 1166 & 27.77 & 5.17 & 2.59 & 11.57 \\
\hline Mean & & $0.21 \mathrm{a}$ & $75844 a$ & $1312 \mathrm{a}$ & $20.90 \mathrm{a}$ & $4.33 \mathrm{a}$ & $2.17 \mathrm{a}$ & $9.68 \mathrm{a}$ \\
\hline Overall Mean & & 0.07 & 90387 & 1397 & 21.31 & 4.38 & 2.19 & 9.79 \\
\hline
\end{tabular}

${ }^{(1)}$ Each uniformity trial of size $8 \mathrm{~m}^{2}(4 \mathrm{~m} \times 2 \mathrm{~m})$ was divided into 16 basic experimental units of $0.5 \mathrm{~m}^{2}(1.0 \mathrm{~m} \times 0.5 \mathrm{~m})$, forming a matrix with four rows and four columns. ${ }^{(2)}$ For each statistic $\left(\rho, s^{2}, m, C V, X o\right.$, and $\left.C_{X_{0}}\right)$, the means not followed by the same letter in the column (comparison of means between the evaluation times) differ, at 5\% probability, by the Tukey test via bootstrap with 10,000 resampling's. 
ranging from -0.38 to 0.45 . The variation coefficient ranged from 12.71 to $31.42 \%$ between the 20 trials, being considered from medium to very high by classification of PIMENTEL-GOMES (2009). On a mean, the variation coefficient was high $(21.33 \%)$.

The optimal plot size in BEUs ranged from 3.15 to 5.71 with a mean value of 4.38 BEUs (Table 1). In the area unit, the optimal plot size ranged from 1.58 to $2.85 \mathrm{~m}^{2}$, with a mean value of $2.19 \mathrm{~m}^{2}$. As expected, trials with higher variability showed higher final values of optimal plot size; however, no differences were observed between evaluation times. The variation coefficient in the optimal plot size ranged from $7.05 \%$ to $12.76 \%$, with a mean value of $9.79 \%$, considered low by classification of PIMENTEL-GOMES (2009). The optimal plot size to determine fresh matter weight of ryegrass $(2.19$ $\mathrm{m}^{2}$ ) is lower than that described in the literature to determine fresh matter weight of other foragers as black oats $\left(4.14 \mathrm{~m}^{2}\right.$ - CARGNELUTTI FILHO et al., 2014), forage pea $\left(5.03 \mathrm{~m}^{2}\right.$ - CARGNELUTTI FILHO et al., 2015), millet (4.97 $\mathrm{m}^{2}$ - BURIN et al., 2016) and vetch (4.52 $\mathrm{m}^{2}$ - CARGNELUTTI FILHO et al., 2017). However, the variation coefficient in the optimal plot size $\left(\mathrm{CV}_{\mathrm{Xo}}=9.79 \%\right)$ was similar to that described for other forages in the abovementioned studies $\left(9.25 \% \leq \mathrm{CV}_{\mathrm{Xo}} \leq 11.24 \%\right)$.

The number of replicates for experiments in completely randomized design, varied between 3.82 replicates (three treatments and $d=20 \%$ ) and 30.69 replicates (50 treatments and $d=10 \%$ - Table 2). For experiments in the randomized complete block design, the number of replications varied between 4.25 (three treatments and $\mathrm{d}=20 \%)$ and 30.69 (50 treatments and $\mathrm{d}=10 \%$ ) (Table 3 ). So, it is verified that to obtain a high precision $(\mathrm{d}=10 \%)$ the number of replications is too high, making experimental conduction unfeasible. For cases of $i=50$ treatments and $d=10 \%$ in completely randomized design and randomized block design experiments, it was verified the need to use 27.41 to 62.98 replications (CARGNELUTTI FILHO et al., 2014, 2015, 2017; BURIN et al., 2016; LAVEZO et al., 2017; CHAVES etal., 2018), indicating the infeasibility of experimental conduction at this precision level.

The replicates number to determine the ryegrass fresh matter weight in a small number of treatments was lower in the completely randomized design in relation to the randomized block design (Tables 2 and 3). This behavior is expected due to the efficiency of the completely randomized design on homogeneous areas and has been described in other experimental planning studies (CARGNELUTTI FILHO et al., 2014, 2015, 2017; BURIN et al., 2016;
LAVEZO et al., 2017; CHAVES et al., 2018). For a high treatments number, the number of replications tends to equalize between the two experimental designs. It has also been reported that the number of replicates increases as the number of treatments increases for fixed $\mathrm{d}$ and $\mathrm{CV}_{\mathrm{Xo}}$. This pattern has also been reported in the literature (CARGNELUTTI FILHO et al., 2014, 2015, 2017; BURIN et al., 2016; LAVEZO et al., 2017; CHAVES et al., 2018).

For the combination of a higher treatments number and lower precision (50 treatments and $\mathrm{d}$ $=20 \%$ ), the number of replications recommended would be 7.79 replications (Tables 2 and 3). As this replications number cannot be used, we can calculate $d$ as a function of eight replications use in completely randomized design and randomized complete block design. Thus, with 50 treatments, for the completely randomized design $\mathrm{d}=\frac{\mathrm{q}_{5 \%(50 ; 350)} \times 9.79}{\sqrt{8}}=\frac{5.699681 \times 9.79}{\sqrt{8}}=19.73 \%$

and for the randomized complete block design $\mathrm{d}=\frac{\mathrm{q}_{5 \%(50 ; 343)} \times 9.79}{\sqrt{8}}=\frac{5.700775 \times 9.79}{\sqrt{8}}=19.73 \%$.

So, in experiments with up to 50 treatments and eight replications, differences between treatment means of $19.73 \%$ of the experiment mean are identified as significant at $5 \%$ probability, by the Tukey test. Still, for experiments with up to five, ten and 20 treatments, five, six and seven replications, respectively, are required to identify as significant at $5 \%$ probability, by the Tukey test, differences between treatment means of $20 \%$ of the experiment mean.

In the evaluation of dry matter in seven populations and three ryegrass cultivars evaluated at two sites, it was used a randomized complete block design with four replications and plots of $3 \mathrm{~m}^{2}(1.5 \mathrm{~m} \times 2 \mathrm{~m})$ in one site and of $6 \mathrm{~m}^{2}$ in another site, with a collection area of $0.25 \mathrm{~m}^{2}$ per plot $(0.5 \mathrm{~m} \times 0.5 \mathrm{~m})$ (FLORES et al., 2008). In an experiment with three different ryegrass managements (treatments) under a succession of corn, it was used a randomized complete block design with three replicates and plots of $100 \mathrm{~m}^{2}(10 \mathrm{~m} \times 10$ $\mathrm{m})$ to evaluate soil physical components under no-till (VIZIOLI et al., 2018). In two experiments conducted in a greenhouse, in a completely randomized design, it was used four and eight replications for the first and second experiment, respectively, with 4 to 128 plants per pot (AGOSTINETTO et al., 2017). Already to evaluate the yield and structural composition of oat and ryegrass subjected to different periods of cutting and nitrogen fertilization, CASSOL et al. (2011) used a randomized complete block design with four 
Table 2 - Number of replications for experiments in the completely randomized design, in scenarios formed by combinations of $i$ treatments $(i=3,4, \ldots, 50)$ and $d$ least differences between treatment means to be detected as significant at $5 \%$ probability by the Tukey test, expressed in percentage of the overall experimental mean $(\mathrm{d}=10,11, \ldots 20 \%)$, to evaluate the fresh matter of ryegrass (Lolium multiflorum L.) - cultivar BRS Ponteio seeded to haul - from optimal plot size $\left(\mathrm{Xo}=2.19 \mathrm{~m}^{2}\right)$ and the variation coefficient in optimal plot size $\left(\mathrm{CV}_{\mathrm{Xo}}=9.79 \%\right)$.

\begin{tabular}{|c|c|c|c|c|c|c|c|c|c|c|c|}
\hline i & $10 \%$ & $11 \%$ & $12 \%$ & $13 \%$ & $14 \%$ & $15 \%$ & $16 \%$ & $17 \%$ & $18 \%$ & $19 \%$ & $20 \%$ \\
\hline 3 & 11.58 & 9.76 & 8.39 & 7.32 & 6.47 & 5.80 & 5.24 & 4.79 & 4.40 & 4.09 & 3.82 \\
\hline 4 & 13.53 & 11.35 & 9.69 & 8.40 & 7.38 & 6.56 & 5.89 & 5.33 & 4.87 & 4.49 & 4.16 \\
\hline 5 & 15.03 & 12.56 & 10.68 & 9.23 & 8.07 & 7.14 & 6.39 & 5.76 & 5.24 & 4.80 & 4.42 \\
\hline 6 & 16.24 & 13.55 & 11.50 & 9.91 & 8.65 & 7.63 & 6.80 & 6.12 & 5.54 & 5.06 & 4.65 \\
\hline 7 & 17.27 & 14.39 & 12.19 & 10.49 & 9.13 & 8.05 & 7.16 & 6.42 & 5.81 & 5.29 & 4.85 \\
\hline 8 & 18.16 & 15.11 & 12.79 & 10.99 & 9.56 & 8.41 & 7.47 & 6.69 & 6.04 & 5.49 & 5.02 \\
\hline 9 & 18.95 & 15.76 & 13.33 & 11.44 & 9.94 & 8.73 & 7.74 & 6.93 & 6.25 & 5.67 & 5.18 \\
\hline 10 & 19.66 & 16.33 & 13.80 & 11.84 & 10.28 & 9.02 & 8.00 & 7.15 & 6.44 & 5.84 & 5.33 \\
\hline 11 & 20.30 & 16.86 & 14.24 & 12.20 & 10.59 & 9.29 & 8.22 & 7.34 & 6.61 & 5.99 & 5.46 \\
\hline 12 & 20.89 & 17.34 & 14.64 & 12.54 & 10.87 & 9.53 & 8.44 & 7.53 & 6.77 & 6.13 & 5.58 \\
\hline 13 & 21.43 & 17.78 & 15.00 & 12.85 & 11.14 & 9.76 & 8.63 & 7.70 & 6.92 & 6.26 & 5.69 \\
\hline 14 & 21.93 & 18.19 & 15.35 & 13.14 & 11.38 & 9.97 & 8.81 & 7.86 & 7.05 & 6.38 & 5.80 \\
\hline 15 & 22.40 & 18.57 & 15.67 & 13.40 & 11.61 & 10.16 & 8.98 & 8.00 & 7.18 & 6.49 & 5.90 \\
\hline 16 & 22.83 & 18.93 & 15.96 & 13.66 & 11.82 & 10.35 & 9.14 & 8.14 & 7.31 & 6.60 & 6.00 \\
\hline 17 & 23.25 & 19.27 & 16.25 & 13.89 & 12.03 & 10.52 & 9.29 & 8.27 & 7.42 & 6.70 & 6.09 \\
\hline 18 & 23.64 & 19.59 & 16.51 & 14.12 & 12.22 & 10.69 & 9.44 & 8.40 & 7.53 & 6.80 & 6.17 \\
\hline 19 & 24.00 & 19.89 & 16.76 & 14.33 & 12.40 & 10.84 & 9.57 & 8.52 & 7.64 & 6.89 & 6.25 \\
\hline 20 & 24.36 & 20.18 & 17.00 & 14.53 & 12.57 & 10.99 & 9.70 & 8.63 & 7.73 & 6.98 & 6.33 \\
\hline 21 & 24.69 & 20.45 & 17.23 & 14.73 & 12.74 & 11.14 & 9.82 & 8.74 & 7.83 & 7.06 & 6.41 \\
\hline 22 & 25.01 & 20.71 & 17.45 & 14.91 & 12.90 & 11.27 & 9.94 & 8.84 & 7.92 & 7.14 & 6.48 \\
\hline 23 & 25.31 & 20.97 & 17.66 & 15.09 & 13.05 & 11.40 & 10.06 & 8.94 & 8.01 & 7.22 & 6.55 \\
\hline 24 & 25.60 & 21.21 & 17.86 & 15.26 & 13.19 & 11.53 & 10.16 & 9.04 & 8.09 & 7.29 & 6.61 \\
\hline 25 & 25.89 & 21.44 & 18.05 & 15.42 & 13.33 & 11.65 & 10.27 & 9.13 & 8.17 & 7.36 & 6.67 \\
\hline 26 & 26.15 & 21.66 & 18.24 & 15.58 & 13.46 & 11.76 & 10.37 & 9.22 & 8.25 & 7.43 & 6.74 \\
\hline 27 & 26.41 & 21.87 & 18.42 & 15.73 & 13.59 & 11.87 & 10.47 & 9.30 & 8.32 & 7.50 & 6.79 \\
\hline 28 & 26.67 & 22.08 & 18.59 & 15.87 & 13.72 & 11.98 & 10.56 & 9.38 & 8.40 & 7.56 & 6.85 \\
\hline 29 & 26.91 & 22.28 & 18.75 & 16.01 & 13.84 & 12.09 & 10.65 & 9.46 & 8.47 & 7.63 & 6.91 \\
\hline 30 & 27.14 & 22.47 & 18.91 & 16.15 & 13.96 & 12.19 & 10.74 & 9.54 & 8.54 & 7.69 & 6.96 \\
\hline 31 & 27.37 & 22.65 & 19.07 & 16.28 & 14.07 & 12.28 & 10.82 & 9.61 & 8.60 & 7.74 & 7.01 \\
\hline 32 & 27.59 & 22.83 & 19.22 & 16.41 & 14.18 & 12.38 & 10.91 & 9.69 & 8.66 & 7.80 & 7.06 \\
\hline 33 & 27.80 & 23.01 & 19.37 & 16.53 & 14.28 & 12.47 & 10.99 & 9.76 & 8.73 & 7.86 & 7.11 \\
\hline 34 & 28.01 & 23.18 & 19.51 & 16.65 & 14.39 & 12.56 & 11.06 & 9.82 & 8.79 & 7.91 & 7.16 \\
\hline 35 & 28.21 & 23.35 & 19.65 & 16.77 & 14.49 & 12.65 & 11.14 & 9.89 & 8.85 & 7.96 & 7.21 \\
\hline 36 & 28.40 & 23.51 & 19.78 & 16.88 & 14.58 & 12.73 & 11.21 & 9.96 & 8.90 & 8.01 & 7.25 \\
\hline 37 & 28.59 & 23.66 & 19.91 & 16.99 & 14.68 & 12.81 & 11.28 & 10.02 & 8.96 & 8.06 & 7.30 \\
\hline 38 & 28.78 & 23.81 & 20.04 & 17.10 & 14.77 & 12.89 & 11.35 & 10.08 & 9.01 & 8.11 & 7.34 \\
\hline 39 & 28.96 & 23.96 & 20.16 & 17.21 & 14.86 & 12.97 & 11.42 & 10.14 & 9.07 & 8.16 & 7.38 \\
\hline 40 & 29.14 & 24.11 & 20.29 & 17.31 & 14.95 & 13.05 & 11.49 & 10.20 & 9.12 & 8.20 & 7.42 \\
\hline 41 & 29.31 & 24.25 & 20.40 & 17.41 & 15.04 & 13.12 & 11.55 & 10.26 & 9.17 & 8.25 & 7.46 \\
\hline 42 & 29.47 & 24.39 & 20.52 & 17.51 & 15.12 & 13.19 & 11.62 & 10.31 & 9.22 & 8.29 & 7.50 \\
\hline 43 & 29.64 & 24.52 & 20.63 & 17.60 & 15.20 & 13.26 & 11.68 & 10.37 & 9.27 & 8.34 & 7.54 \\
\hline 44 & 29.80 & 24.65 & 20.74 & 17.70 & 15.28 & 13.33 & 11.74 & 10.42 & 9.31 & 8.38 & 7.58 \\
\hline 45 & 29.95 & 24.78 & 20.85 & 17.79 & 15.36 & 13.40 & 11.80 & 10.47 & 9.36 & 8.42 & 7.62 \\
\hline 46 & 30.11 & 24.91 & 20.96 & 17.88 & 15.44 & 13.47 & 11.86 & 10.52 & 9.40 & 8.46 & 7.65 \\
\hline 47 & 30.26 & 25.03 & 21.06 & 17.97 & 15.51 & 13.53 & 11.91 & 10.57 & 9.45 & 8.50 & 7.69 \\
\hline 48 & 30.40 & 25.15 & 21.16 & 18.05 & 15.59 & 13.60 & 11.97 & 10.62 & 9.49 & 8.54 & 7.72 \\
\hline 49 & 30.55 & 25.27 & 21.26 & 18.14 & 15.66 & 13.66 & 12.02 & 10.67 & 9.53 & 8.57 & 7.76 \\
\hline 50 & 30.69 & 25.39 & 21.36 & 18.22 & 15.73 & 13.72 & 12.08 & 10.72 & 9.58 & 8.61 & 7.79 \\
\hline
\end{tabular}


Table 3 - Number of replications for experiments in the randomized complete block design, in scenarios formed by combinations of $i$ treatments $(i=3,4, \ldots$, 50) and d least differences between treatment means to be detected as significant at $5 \%$ probability by the Tukey test, expressed in percentage of the overall experimental mean $(\mathrm{d}=10,11, \ldots 20 \%)$, to evaluate the fresh matter of ryegrass (Lolium multiflorum L.) - cultivar BRS Ponteio seeded to haul - from optimal plot size $\left(\mathrm{Xo}=2.19 \mathrm{~m}^{2}\right)$ and the variation coefficient in optimal plot size $\left(\mathrm{CV}_{\mathrm{Xo}_{\mathrm{o}}}=9.79 \%\right)$.

\begin{tabular}{|c|c|c|c|c|c|c|c|c|c|c|c|}
\hline $\mathrm{i}$ & $10 \%$ & $11 \%$ & $12 \%$ & $13 \%$ & $14 \%$ & $15 \%$ & $16 \%$ & $17 \%$ & $18 \%$ & $19 \%$ & $20 \%$ \\
\hline 3 & 12.08 & 10.26 & 8.89 & 7.81 & 6.96 & 6.28 & 5.73 & 5.26 & 4.88 & 4.54 & 4.25 \\
\hline 4 & 13.82 & 11.63 & 9.97 & 8.68 & 7.66 & 6.84 & 6.16 & 5.61 & 5.15 & 4.75 & 4.42 \\
\hline 5 & 15.21 & 12.75 & 10.87 & 9.41 & 8.26 & 7.33 & 6.57 & 5.94 & 5.42 & 4.98 & 4.61 \\
\hline 6 & 16.38 & 13.68 & 11.63 & 10.04 & 8.78 & 7.76 & 6.94 & 6.25 & 5.68 & 5.20 & 4.78 \\
\hline 7 & 17.37 & 14.48 & 12.29 & 10.59 & 9.23 & 8.15 & 7.26 & 6.52 & 5.91 & 5.39 & 4.95 \\
\hline 8 & 18.24 & 15.19 & 12.87 & 11.07 & 9.64 & 8.49 & 7.55 & 6.77 & 6.12 & 5.57 & 5.10 \\
\hline 9 & 19.01 & 15.82 & 13.39 & 11.50 & 10.00 & 8.80 & 7.81 & 6.99 & 6.31 & 5.74 & 5.25 \\
\hline 10 & 19.71 & 16.38 & 13.86 & 11.89 & 10.33 & 9.08 & 8.05 & 7.20 & 6.49 & 5.89 & 5.38 \\
\hline 11 & 20.34 & 16.90 & 14.28 & 12.25 & 10.63 & 9.33 & 8.27 & 7.39 & 6.65 & 6.03 & 5.50 \\
\hline 12 & 20.92 & 17.37 & 14.67 & 12.58 & 10.91 & 9.57 & 8.47 & 7.57 & 6.81 & 6.17 & 5.62 \\
\hline 13 & 21.46 & 17.81 & 15.04 & 12.88 & 11.17 & 9.79 & 8.66 & 7.73 & 6.95 & 6.29 & 5.73 \\
\hline 14 & 21.96 & 18.22 & 15.37 & 13.16 & 11.41 & 10.00 & 8.84 & 7.88 & 7.08 & 6.41 & 5.83 \\
\hline 15 & 22.42 & 18.60 & 15.69 & 13.43 & 11.64 & 10.19 & 9.01 & 8.03 & 7.21 & 6.52 & 5.93 \\
\hline 16 & 22.86 & 18.95 & 15.99 & 13.68 & 11.85 & 10.37 & 9.16 & 8.17 & 7.33 & 6.62 & 6.02 \\
\hline 17 & 23.27 & 19.29 & 16.27 & 13.91 & 12.05 & 10.54 & 9.31 & 8.29 & 7.44 & 6.72 & 6.11 \\
\hline 18 & 23.65 & 19.61 & 16.53 & 14.14 & 12.24 & 10.71 & 9.45 & 8.42 & 7.55 & 6.82 & 6.19 \\
\hline 19 & 24.02 & 19.91 & 16.78 & 14.35 & 12.42 & 10.86 & 9.59 & 8.53 & 7.65 & 6.91 & 6.27 \\
\hline 20 & 24.37 & 20.19 & 17.02 & 14.55 & 12.59 & 11.01 & 9.72 & 8.65 & 7.75 & 6.99 & 6.35 \\
\hline 21 & 24.70 & 20.47 & 17.25 & 14.74 & 12.75 & 11.15 & 9.84 & 8.75 & 7.84 & 7.08 & 6.42 \\
\hline 22 & 25.02 & 20.73 & 17.46 & 14.92 & 12.91 & 11.28 & 9.96 & 8.85 & 7.93 & 7.15 & 6.49 \\
\hline 23 & 25.32 & 20.98 & 17.67 & 15.10 & 13.06 & 11.41 & 10.07 & 8.95 & 8.02 & 7.23 & 6.56 \\
\hline 24 & 25.62 & 21.22 & 17.87 & 15.27 & 13.20 & 11.54 & 10.18 & 9.05 & 8.10 & 7.30 & 6.62 \\
\hline 25 & 25.89 & 21.45 & 18.06 & 15.43 & 13.34 & 11.66 & 10.28 & 9.14 & 8.18 & 7.37 & 6.69 \\
\hline 26 & 26.16 & 21.67 & 18.25 & 15.58 & 13.47 & 11.77 & 10.38 & 9.23 & 8.26 & 7.44 & 6.75 \\
\hline 27 & 26.42 & 21.88 & 18.42 & 15.74 & 13.60 & 11.88 & 10.48 & 9.31 & 8.33 & 7.51 & 6.80 \\
\hline 28 & 26.67 & 22.08 & 18.60 & 15.88 & 13.73 & 11.99 & 10.57 & 9.39 & 8.41 & 7.57 & 6.86 \\
\hline 29 & 26.92 & 22.28 & 18.76 & 16.02 & 13.85 & 12.09 & 10.66 & 9.47 & 8.48 & 7.63 & 6.92 \\
\hline 30 & 27.15 & 22.48 & 18.92 & 16.16 & 13.96 & 12.19 & 10.75 & 9.55 & 8.54 & 7.69 & 6.97 \\
\hline 31 & 27.37 & 22.66 & 19.08 & 16.29 & 14.07 & 12.29 & 10.83 & 9.62 & 8.61 & 7.75 & 7.02 \\
\hline 32 & 27.59 & 22.84 & 19.23 & 16.41 & 14.18 & 12.38 & 10.91 & 9.69 & 8.67 & 7.81 & 7.07 \\
\hline 33 & 27.81 & 23.02 & 19.37 & 16.54 & 14.29 & 12.48 & 10.99 & 9.76 & 8.73 & 7.86 & 7.12 \\
\hline 34 & 28.01 & 23.19 & 19.51 & 16.66 & 14.39 & 12.56 & 11.07 & 9.83 & 8.79 & 7.92 & 7.17 \\
\hline 35 & 28.21 & 23.35 & 19.65 & 16.78 & 14.49 & 12.65 & 11.14 & 9.90 & 8.85 & 7.97 & 7.21 \\
\hline 36 & 28.41 & 23.51 & 19.79 & 16.89 & 14.59 & 12.74 & 11.22 & 9.96 & 8.91 & 8.02 & 7.26 \\
\hline 37 & 28.60 & 23.67 & 19.92 & 17.00 & 14.68 & 12.82 & 11.29 & 10.02 & 8.96 & 8.07 & 7.30 \\
\hline 38 & 28.78 & 23.82 & 20.04 & 17.11 & 14.78 & 12.90 & 11.36 & 10.09 & 9.02 & 8.12 & 7.34 \\
\hline 39 & 28.96 & 23.97 & 20.17 & 17.21 & 14.87 & 12.97 & 11.43 & 10.14 & 9.07 & 8.16 & 7.39 \\
\hline 40 & 29.14 & 24.11 & 20.29 & 17.31 & 14.95 & 13.05 & 11.49 & 10.20 & 9.12 & 8.21 & 7.43 \\
\hline 41 & 29.31 & 24.25 & 20.41 & 17.41 & 15.04 & 13.13 & 11.56 & 10.26 & 9.17 & 8.25 & 7.47 \\
\hline 42 & 29.48 & 24.39 & 20.52 & 17.51 & 15.12 & 13.20 & 11.62 & 10.32 & 9.22 & 8.30 & 7.51 \\
\hline 43 & 29.64 & 24.53 & 20.64 & 17.61 & 15.21 & 13.27 & 11.68 & 10.37 & 9.27 & 8.34 & 7.54 \\
\hline 44 & 29.80 & 24.66 & 20.75 & 17.70 & 15.29 & 13.34 & 11.74 & 10.42 & 9.32 & 8.38 & 7.58 \\
\hline 45 & 29.96 & 24.79 & 20.85 & 17.79 & 15.36 & 13.41 & 11.80 & 10.48 & 9.36 & 8.42 & 7.62 \\
\hline 46 & 30.11 & 24.91 & 20.96 & 17.88 & 15.44 & 13.47 & 11.86 & 10.53 & 9.41 & 8.46 & 7.65 \\
\hline 47 & 30.26 & 25.04 & 21.06 & 17.97 & 15.52 & 13.54 & 11.92 & 10.58 & 9.45 & 8.50 & 7.69 \\
\hline 48 & 30.41 & 25.16 & 21.16 & 18.06 & 15.59 & 13.60 & 11.97 & 10.63 & 9.50 & 8.54 & 7.72 \\
\hline 49 & 30.55 & 25.28 & 21.26 & 18.14 & 15.66 & 13.66 & 12.03 & 10.67 & 9.54 & 8.58 & 7.76 \\
\hline 50 & 30.69 & 25.39 & 21.36 & 18.22 & 15.73 & 13.72 & 12.08 & 10.72 & 9.58 & 8.61 & 7.79 \\
\hline
\end{tabular}

Ciência Rural, v.50, n.1, 2020. 
replications and plots of $108 \mathrm{~m}^{2}(6 \mathrm{~m} \times 18 \mathrm{~m})$ and subplots of $36 \mathrm{~m}^{2}(6 \mathrm{~m} \times 6 \mathrm{~m})$.

\section{CONCLUSION}

The optimal plot size to determine the fresh matter weight of ryegrass seeded at the haul is $2.19 \mathrm{~m}^{2}$, with a variation coefficient of $9.79 \%$. To identify as significant at $5 \%$ probability, by the Tukey test, differences between treatment means of $20 \%$, are required five, six, seven and eight replications, respectively, in ryegrass experiments with up to five, ten, 20 and 50 treatments.

\section{ACKNOWLEDGEMENTS}

To the Fundação de Amparo à Pesquisa do Estado do Rio Grande do Sul (FAPERGS - Process no. 16/2551-00002576 ARD/PPP) by financial support. To Conselho Nacional de Desenvolvimento Científico e Tecnológico $(\mathrm{CNPq}$ - Process no. 304652/2017-2) for the research grant of the second author. To the CNPq, to the FAPERGS, to the Programa de Educação Tutorial do Ministério da Educação and to the Universidade Federal do Pampa by scholarships. To the Coordenação de Aperfeiçoamento de Pessoal de Nível Superior (CAPES), Brasil - Finance code 001.

\section{DECLARATION OF CONFLICT OF} INTERESTS

The authors declare no conflict of interest. The founding sponsors had no role in the design of the study; in the collection, analyses, or interpretation of data; in the writing of the manuscript, and in the decision to publish the results.

\section{AUTHORS' CONTRIBUTIONS}

MT conceived, designed and supervised the experiment. JOC, FLT, AFC, ACM and PJM performed the experiments and data collection. ACF performed the statistical analyses. MT and ACF prepared the draft of the manuscript. All authors critically revised the manuscript and approved of the final version.

\section{REFERENCES}

AGOSTINETTO, D. et al. Metabolic activity of wheat and ryegrass plants in competition. Planta Daninha, v.35, p.17, 2017. Available from: <http://dx.doi.org/10.1590/S010083582017350100044>. Accessed: Mar. 29, 2019. doi: 10.1590/ S0100-83582017350100044.

BISCAIINO, L.L. et al. Beef heifers performance in ryegrass pasture supplemented with rice bran with or without monensin. Arquivo Brasileiro de Medicina Veterinária e Zootecnia, v.70, p.881-887, 2018. Available from: <https://dx.doi.org/10.1590/1678-41629463 >. Accessed: Mar. 07, 2019. doi: 10.1590/1678-4162-9463.

BURIN, C. et al. Plotsize and number of replicates in times of sowing and cuts of millet. Revista Brasileira de Engenharia Agrícola e Ambiental, v.20, p.119-127, 2016. Available from: $<$ https://dx.doi. org/10.1590/1807-1929/agriambi.v20n2p119-127>. Accessed: Mar. 07, 2019. doi: 10.1590/1807-1929/agriambi.v20n2p119-127.

CARGNELUTTI FILHO, A. et al. Plot size and number of repetitions in vetch. Bragantia, v.76, p.178-188, 2017. Available from: <https://dx.doi.org/10.1590/1678-4499.084>. Accessed: Mar. 07, 2019. doi: 10.1590/1678-4499.084.

CARGNELUTTI FILHO, A. et al. Plot size and number of repetitions in black oat. Ciência Rural, v.44, p.1732-1739, 2014. Available from: <https://dx.doi.org/10.1590/01038478cr20131466>. Accessed: Mar. 07, 2019. doi: 10.1590/0103$8478 \mathrm{cr} 20131466$.

CARGNELUTTI FILHO, A. et al. Plot size and number of repetitions in forage pea. Ciência Rural, v.45, p.1174-1182, 2015. Available from: <https://dx.doi.org/10.1590/01038478cr20141043>. Accessed: Mar. 07, 2019. doi: 10.1590/0103$8478 \mathrm{cr} 20141043$.

CASSOL, L. C.et al. Yield and structural composition of oat and ryegrass subjected to different periods of cutting and nitrogen fertilization. Revista Ceres, v.58, p.438-443, 2011. Available from: <http://dx.doi.org/10.1590/S0034-737X2011000400006>. Accessed: Set. 17,2019. doi: 10.1590/S0034-737X2011000400006.

CHAVES, G.G. et al. Plot size and number of replications for evaluation of the yield of grains in cultivars and dates of sowing of rye. Journal of Agricultural Science, v.10, p.122-132, 2018. Available from: <http://dx.doi.org/10.5539/jas.v10n1p122>. Accessed: Mar. 07, 2019. doi: 10.5539/jas.v10n1p122.

CQFS - Comissão de Química e Fertilidade do Solo. Manual de adubação e de calagem para os Estados do Rio Grande do Sul e de Santa Catarina. $10^{\mathrm{a}}$ ed. Porto Alegre: Sociedade Brasileira de Ciência do Solo. 2004, 400 p.

FERREIRA, D.F. Sisvar: A guide for its bootstrap procedures in multiple comparisons. Ciência e Agrotecnologia, v.38, p.109-112, 2014. Available from: <http://www.scielo.br/pdf/cagro/v38n2/ a01v38n2.pdf $>$. Accessed: Mar. 07, 2019.

FLORES, R.A. et al. Forage production of annual ryegrass populations in the state of Rio Grande do Sul, Brazil. Revista Brasileira de Zootecnia, v. 37, p.1168-1175, 2008. Available from: <http://dx.doi.org/10.1590/S1516-35982008000700005>. Accessed:Mar.29,2019.doi: 10.1590/S1516-35982008000700005.

LAVEZO, A. et al. Plot size and number of replications to evaluate the grain yield in oat cultivars. Bragantia, v.76, p.512520 , 2017. Available from: <https://dx.doi.org/10.1590/16784499.2016.410>. Accessed: Mar. 07, 2019. doi: 10.1590/16784499.2016 .410

PARANAÍBA, P.F. et al. Optimum experimental plot size: proposition of estimation methods. Revista Brasileira de Biometria, v.27, p.255-268, 2009. Available from: <http:// jaguar.fcav.unesp.br/RME/fasciculos/v27/v27_n2/Patricia.pdf>. Accessed: Mar. 07, 2019.

PIMENTEL-GOMES, F. Curso de estatística experimental. $15^{\mathrm{a}}$ ed. Piracicaba: FEALQ, 2009. 451 p.

RIBEIRO FILHO, H. M. N. et al. Herbage intake and milk yield of dairy cows grazing Italian ryegrass at two herbage allowances. Revista Brasileira de Zootecnia, v.38, p.2038- 
2044, 2009. Available from <http://dx.doi.org/10.1590/S151635982009001000026>. Accessed: Set. 17, 2019. doi: 10.1590/ S1516-35982009001000026.

SANTOS, H.G. et al. Sistema brasileiro de classificação de solos. Brasília: EMBRAPA, 2013. 353 p.

STORCK, L. et al. Experimentação vegetal. $3^{a}$ ed. Santa Maria: UFSM, 2016. $200 \mathrm{p}$.
VIZIOLI, B. et al. Influence of ryegrass managements on the physical properties of a Haplohumox. Pesquisa Agropecuária Brasileira, v. 53, p.952-960, 2019. Available from: <https://doi. org/10.1590/S0100-204X2018000800010>. Accessed: Mar. 29, 2019. doi: $10.1590 / \mathrm{S} 0100-204 X 2018000800010$.

WREGE, M.S. et al. Atlas climático da Região Sul do Brasil: Estados do Paraná, Santa Catarina e Rio Grande do Sul. $2^{\mathrm{a}}$ ed. Brasília: EMBRAPA, 2012. 333 p. 